\title{
Prolactin receptor in breast cancer: marker for metastatic risk
}

\section{Carrie S Shemanko}

Department of Biological Sciences, Charbonneau Cancer Institute, University of Calgary, Calgary, Alberta, Canada
Correspondence should be addressed

to C S Shemanko

Email

Shemanko@ucalgary.ca

\begin{abstract}
Prolactin and prolactin receptor signaling and function are complex in nature and intricate in function. Basic, pre-clinical and translational research has opened up our eyes to the understanding that prolactin and prolactin receptor signaling function differently within different cellular contexts and microenvironmental conditions. Its multiple roles in normal physiology are subverted in cancer initiation and progression, and gradually we are teasing out the intricacies of function and therapeutic value. Recently, we observed that prolactin has a role in accelerating the time to bone metastasis in breast cancer patients and identified the mechanism by which prolactin stimulated breast cancer cellmediated lytic osteoclast formation. The possibility that the prolactin receptor is a marker for metastasis, and specifically bone metastasis, is one that may have to be put into the context of the different variants of prolactin, different prolactin receptor isoforms and intricate signaling pathways that are regulated by the microenvironment. The more complete the picture, the better one can test biomarker identity and design clinical trials to test therapeutic intervention. This review will cover the recent advances and highlight the complexity of prolactin receptor biology.
\end{abstract}

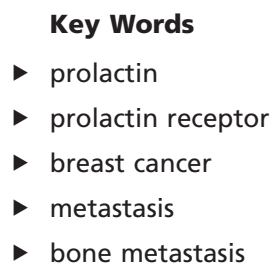

Journal of Molecular Endocrinology (2016) 57, R153-R165

\section{Introduction}

The complexity of prolactin (PRL) signaling and function in breast cancer biology is apparent, with multiple reports covering a spectrum of observations that range from a protective nature to the induction of lytic bone cells in the metastatic process of breast cancer. The intricacy of these conflicting observations intriguingly lies somewhere in the spectrum of signaling pathways, involving multiple receptor isoforms and the interaction of the breast cancer cells with the cells and molecules in the tumor microenvironment. This review will explore the potential of the PRL receptor (PRLR) to be used as a biomarker for metastatic risk, within the spectrum of the roles of prolactin signaling, in early breast cancer initiation to breast cancer metastasis to bone.

\section{PRL and the risk of breast cancer and metastasis}

There have been some extensive investigations using large prospective cohorts to assess the risk of primary breast cancer in women with high levels of circulating PRL (Tworoger et al. 2013, Tikk et al. 2014). In the Nurses Heath Study, it was found that PRL levels measured less than 10 years before diagnosis (2468 cases and 4021 controls), as opposed to greater than 10 years (953 cases and 1339 controls), was associated with postmenopausal breast cancer risk (relative risk (RR), $>15.7$ vs $\leq 8.1 \mathrm{ng} / \mathrm{mL}$ (i.e., top vs bottom quartiles) $=1.20$; $95 \% \mathrm{CI}, 1.03-1.40$; $P_{\text {trend }}=0.005$ ), particularly for estrogen receptor (ER)positive tumors (RR 1.52) and lymph node-positive disease (RR 1.63). The associations were similar for grade, tumor size, ductal vs lobular tumors, human

Published by Bioscientifica Ltd. 
epidermal growth factor receptor (HER)-2 status, as well as for luminal A vs B subtypes $\left(P_{\text {heterogeneity }}>0.46\right)$, but apparently stronger for invasive tumors (RR 1.38, $\left.P_{\text {trend }}=0.0005\right)$ compared with in situ tumors (RR 1.16, $\left.P_{\text {trend }}=0.23\right)$, although the $P_{\text {heterogeneity }}$ was not statistically significant $(P=0.81)$. The association with triple-negative tumors, recurrent or fatal disease, was not significant (Tworoger et al. 2013).

The association of PRL levels with ER-positive disease is very interesting, given the predominance of ER-positive tumors associated with bone metastasis (Hess et al. 2003, Wei et al. 2008) and the recent observations of PRL affecting breast cancer cell communication with bone cells (see PRLR and bone metastasis) (Sutherland et al. 2016).

Another group investigating a subgroup of the European Prospective Investigation into Cancer and Nutrition (EPIC) cohort (2250 invasive breast cancer patients with equal number of matched control subjects) demonstrated an increase in risk among postmenopausal breast cancer patients (odds ratio $(\mathrm{OR})_{\mathrm{Q} 4-\mathrm{Q} 1}=1.29$ (95\% confidence interval (CI) 1.05-1.58), $P_{\text {trend }}=0.09$ ), particularly those women who had hormone replacement therapy $\left(\mathrm{OR}_{\mathrm{Q} 4-\mathrm{Q} 1}=1.45\right.$ (95\% CI 1.08-1.95), $\left.P_{\text {trend }}=0.01\right)$ (Tikk et al. 2014).

So there is an association of invasive breast cancer risk in postmenopausal women with high circulating PRL, particularly for ER-positive disease. Interestingly, there was no significant association with disease

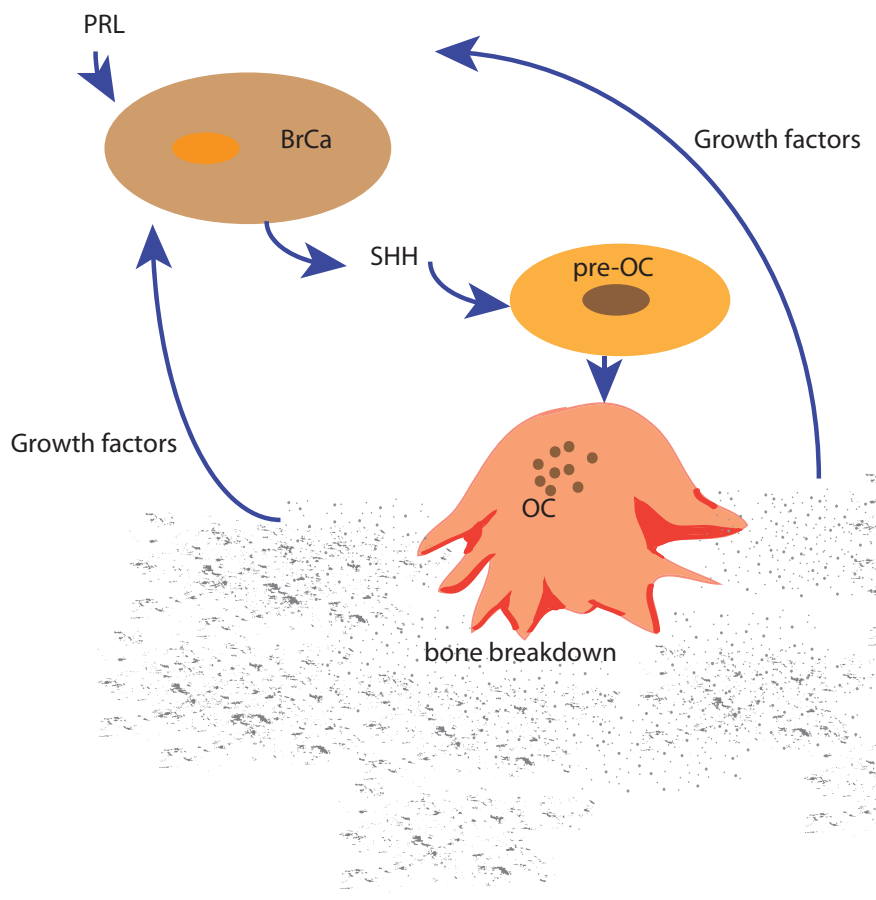

recurrence, similar to another report using a very small cohort (Coskun et al. 2003).

\section{PRLR and bone metastasis}

Although there is a known association of PRL levels with invasive breast cancer, information about the role of PRL in metastasis has been lacking until recently (Yonezawa et al. 2015, Sutherland et al. 2016). We recently reported the involvement of PRL signaling in breast cancer bone metastases (Fig. 1) (Sutherland et al. 2016). In a retrospective cohort (134 patient samples) of breast cancer primary tumor samples, we identified, using quantitative immunohistochemistry, an association of the PRLR (monoclonal antibody 1A2B1 to receptor extracellular domain) with a shorter time to metastasis that includes bone $\left(P_{\text {PRLR }}\right.$ AQUA Max-per 100 unit hazard ratio $=1.04,95 \%$ $\mathrm{CI}=1.00-1.07, P=0.03)$. There was no association with any other location, and the PRLR was an independent marker. We also observed that the PRLR was present in a second set of primary breast tumor tissues with matched bone metastases. Interestingly, there was variable PRLR staining between the matched samples, such that there could be high or low staining in the primary tumor, with either high or low staining in the matched bone metastasis. This may be due to technical issues common to bone preparations, but it may also be explained by heterogeneous PRLR levels also detected in advanced breast cancer patient circulating tumor cells (Sutherland et al. 2016).

\begin{abstract}
Figure 1
PRL stimulates breast cancer cells to secrete soluble factors, such as $\mathrm{SHH}$, which instructs pre-osteoclasts to differentiate and become lytic, mature, multi-nucleated osteoclasts. The breakdown of the bone has been reported to release calcium and growth factors, which stimulate tumor cell reproduction, resulting in a vicious cycle.
\end{abstract}


Given the association of high PRLR with a shorter time to bone metastases, we hypothesized that high PRLR may be involved in creating a more serious bone lesion upon metastasis (Fig. 1) (Sutherland et al. 2016). We asked if the PRLR present on the breast cancer cells could contribute to bone breakdown (osteolysis) and investigated whether there would be a direct contribution of PRL-induced breast cancer cells to the induction of bone osteoclasts. As osteoclast cells do not express the PRLR at the gene or protein level (Clement-Lacroix et al. 1999, Coss et al. 2000), the PRL effect would be mediated by the PRLR on the breast cancer cells. Indeed, PRL was capable of inducing osteoclast differentiation when the breast cancer cells were either co-cultured with osteoclasts or when breast cancer conditioned medium was used, and PRL also contributed to breast cancer-mediated osteolysis. Interestingly, different PRLR-positive breast cancer cell lines responded somewhat differently, with PRL-treated MCF7 cells producing the greatest number of osteoclasts only when in co-culture with osteoclasts, in comparison with PRL-treated MCF7-conditioned medium. SKBr3 and BT-483 were able to induce osteoclasts via conditioned media in a PRL-dependent manner. MCF7 cells have been identified as luminal breast cancer cells (Neve et al. 2006, Kao et al. 2009), luminal B in particular (Prat et al. 2013). SKBr3 was identified as a luminal molecular subtype (Kao et al. 2009), particularly luminal B with HER2 overexpression (Prat et al. 2013). BT-483 cells have been reported as luminal (Neve et al. 2006), luminal B without HER2 expression (Kao et al. 2009) or luminal B with HER2 overexpression (Prat et al. 2013). The differences in cellular response of MCF7 from other PRLR-positive cell lines may reflect alternate PRLR signaling pathways, different posttranscriptional processing of PRL-regulated targets such as sonic hedgehog ( $\mathrm{SHH}$ ) or a difference in qualitative response between the cell lines.

In this investigation, $\mathrm{SHH}$ was identified as PRL-enhanced in the conditioned medium of different PRL-responsive cell lines (Fig. 1), but not in MCF7 cells. SHH has been demonstrated to stimulate osteoclast differentiation (Das et al. 2011, Sutherland et al. 2016), and a hedgehog pathway (smoothened) inhibitor, cyclopamine (Chen et al. 2002), reduced PRL-induced breast cancer cell-mediated osteoclastogenesis (Sutherland et al. 2016).

The two retrospective cohorts in this study were chosen with an interest in bone metastasis and contained a number of advanced breast cancer patients. As such, it will be interesting to follow-up this study with a prospective cohort such as the Breast to Bone Metastasis (B2B) cohort (Brockton et al. 2015). The results indicate that PRLR signaling may be an important marker for breast cancer bone metastasis, and that the PRLR is present in such bone metastases and likely to have a deleterious impact on the level of osteolysis in vivo. This builds on other work that has identified a vicious cycle of bone metastasis (Fig. 1), whereby breast cancer-secreted factors can act on the osteoblast or osteoclasts of the bone to induce bone breakdown. The release of bone-matrix factors stimulates cancer cell reproduction and begins a vicious cycle of bone breakdown and tumor cell growth, which PRL would accelerate or perpetuate. It will be interesting to identify the key PRLR isoforms and contributing pathways involved in this process.

Patients, in particular those, who have hormone receptor-positive (ER and/or progesterone receptor) boneonly breast cancer metastases have an excellent clinical outcome (Lee et al. 2011). Patients with bone metastases have high levels of morbidity, and better identification of these patients, combined with better treatment, could significantly improve their quality of life. The studies by Sutherland and coworkers assessed all metastases that included bone. In future, it will be important to stratify PRLR-positive patients based on organ-specific relapse. A report on 85 breast cancer patients and 25 controls showed that there was no association of serum PRL levels with visceral or bone metastases (Coskun et al. 2003), so information regarding the PRLR is essential. Identifying the roles of PRL-PRLR in specific stages of metastases, whether the metastases are preferentially boney or visceral and if PRL-PRLR is involved in homing to any specific secondary site will help clarify the observations in the literature and highlight the importance of proper patient identification when using anti-PRL or anti-PRLR cancer treatments.

\section{The long form of the PRLR is responsible for metastasis}

The PRLR gene has the potential to produce multiple isoforms (see PRLR structure and isoforms). Recently, the role of the long PRLR isoform was investigated (Yonezawa et al. 2015). Splice-modulating oligomers were delivered in vivo to block splicing between Prlr exons 9 and 10, reducing the amount of the fulllength PRLR, but not SF1a-c, and not of the related growth hormone receptor. The intermediate form of the receptor was not considered an abundant isoform in

Published by Bioscientifica Ltd 
the study. There was a knockdown of the long isoform in the mammary gland, liver and ovary. Interestingly, specific knockdown of the long isoform resulted in a sharp decrease in metastatic colonization of the lungs and liver from orthotopic mammary fat pad transplants of syngeneic $4 \mathrm{~T} 1$ cells in Balb/c mice. The observations were replicated in a humanized xenograft model, using BT474 cells in non-obese diabetic severe combined immunodeficiency (NOD-SCID) mice (Yonezawa et al. 2015) (BT474, luminal B-like with Her2 overexpression (Neve et al. 2006, Prat et al. 2013)).

The use of both the xenograft and syngeneic models allowed an interesting opportunity to study the role of the native immune system also. It was observed that knockdown of the PRLR long form resulted in decreased immune infiltration of the metastatic sites by neutrophils and macrophage and increased anti-tumor cytotoxic CD8+ cells. Interestingly, a lack of ability of oligomertreated 4T1 cells to form primary spheres in non-adherent culture, and an apoptotic reduction in cells with the tumorinitiating phenotype, Lin- CD24+CD29hi ALDH+, was also noted. This study demonstrated that the long form of the PRLR contributed significantly to the development of both lung and liver metastases in these mouse models. It would be very interesting to assess its contribution to bone and brain metastases.

A number of different mouse models of increased mammary PRL, including mouse models of mammary cancer, have been studied for the effects of PRL on mammary cancer and metastasis and interaction with specific oncogenes. These have been comprehensively reviewed (Arendt \& Schuler 2008b).

\section{PRLR and clinical outcome by breast cancer molecular subtype}

What is known about the PRLR in breast cancer molecular subtypes? Can their biology inform our understanding of the different roles of the PRLR in breast cancer? There have been two recent reports of PRL and PRLR levels and gene expression (Hachim et al. 2016a,b).

Interrogation of a small tissue micro-array (TMA) (100 patients) for PRL and PRLR levels showed an association of PRL with lymph node-positive patients, although there was no detection of the PRLR in the cancer samples (polyclonal antibody H-300 to the PRLR intracellular domain) (Hachim et al. 2016b). Interrogation of the KM-Plotter database using the PRL gene identified an association with prolonged relapse-free survival. A gene signature, of PRL, PRLR, Janus kinase (JAK)-2 and signal transducer and activator of transcription (STAT)-5a (derived from 1881 GOBO (Gene expression-based Outcome for Breast cancer Online (GOBO) patients)), was used to assess the GOBO database. This analysis demonstrated an association with ER-positive and luminal A subtypes, as well as with prolonged relapse-free survival (Hachim et al. 2016b). A PRL gene signature derived from differentiated PRL-induced mammary epithelial HC11 cells was also found to be associated with well-differentiated tumors and luminal A tumors (Hachim et al. 2016b). This is as may be expected, given the association of this pathway with mammary epithelial cell differentiation and early tumorigenesis (see PRL-JAK2-STAT5 signaling).

Using a small TMA (102 patients) with immunohistochemistry, analysis of PRLR levels and its gene expression was undertaken (Hachim et al. 2016a). Cores of the small TMA were reclassified on the basis of immunohistochemical markers, as surrogates of the molecular subtype, and found the PRLR (polyclonal antibody $\mathrm{H}-300$ to the receptor intracellular domain) was present in luminal, A, luminal B and Her2-enriched, but not in triple-negative patient tumors. A larger analysis was carried out at the mRNA levels in a cohort of the GOBO (1881 patients) database (Hachim et al. 2016a). There was no evidence of association of PRLR expression with hormone receptors, although an association of $P R L R$ expression and the luminal A subtype was observed, and there was no evidence of association with the basal subtype. Analysis of 21 subtypes (in a subset of 1379 patients) resulted in a significant association of PRLR expression with better distant metastasis-free survival in luminal B (PAM50 and $\mathrm{Hu}$ classifications) patients (Hachim et al. 2016a). In future, it would be very interesting to discover which receptor variants are predominantly expressed in each of these molecular subtypes and which pathway may be preferentially activated within each subtype.

\section{Key factors influencing PRLR biology}

The link of PRL levels to invasive breast cancer risk (Tworoger et al. 2013, Tikk et al. 2014) implies a connection to primary tumor initiation and also to metastatic capacity. PRL and the long form of the PRLR also contribute to the metastatic process (Yonezawa et al. 2015). These results are consistent with the reports of PRLR-mediated chemotherapeutic resistance (Howell et al. 2008, LaPensee et al. 2009) and the role of PRLPRLR in osteolytic bone metastases of breast cancer cells (Sutherland et al. 2016). The recent demonstration of PRL and PRLR mRNA and protein in tumor-initiating cells

Published by Bioscientifica Ltd 
warrants additional follow-up, and their roles in apoptosis and sphere formation may indicate a contribution to early tumorigenesis, metastasis and chemotherapy resistance, consistent with the role of tumor-initiating cells in cancer. Interestingly, the recent evidence also indicates that PRL and PRLR expression is associated with relapsefree survival and distant metastasis-free survival of breast cancer patients (Hachim et al. 2016a,b).

So how can these findings be reconciled, aside from the potential differences resulting from different experimental platforms and breast cancer cohort selection? The key to understanding these results that appear to be conflicting on the surface of our knowledge, likely lies in what we do not yet fully understand: the intricate nature of PRL and PRLR biology, discussed in the following sections.

\section{Pituitary and extra-pituitary PRL, PRL isoforms and alternative ligands}

The complexity of PRL signaling and the spectrum of biological response start with the potential for different prolactin isoforms to be produced (Bernard et al. 2015). Prolactin is produced in an endocrine manner in the anterior pituitary gland, as well as secreted in an extrapituitary, autocrine/paracrine manner from normal breast and breast tumor tissue. The major isoform, the $23 \mathrm{kDa}$ protein, is proteolytically cleaved to $14 \mathrm{kDa}, 16 \mathrm{kDa}$ and $22 \mathrm{kDa}$ isoforms (Bernard et al. 2015). Although the $16 \mathrm{kDa}$ fraction cannot interact with the PRLR, it functions as an anti-angiogenic molecule (vasoinhibin) by interacting with endothelial cells, in contrast to the full-length form of PRL, which is vasoactive (Clapp et al. 2008).

Both normal breast tissue and breast tumors secrete extra-pituitary prolactin, which is thought to act in an autocrine/paracrine manner in the microenvironment (Ben-Jonathan et al. 2002). Although the two sources produce identical proteins, the level, post-translational modifications, and microenvironmental function of autocrine prolactin is not taken into consideration in the majority of studies. Autocrine $P R L$ was detected in nearly half of 144 breast cancer samples by cDNA array, in situ hybridization or PCR, albeit generally at very low levels (Nitze et al. 2013).

Although PRL appears to only bind to the PRLR, the PRLR can bind three different ligands (PRL, placental lactogen and growth hormone (Brooks 2012)) leading to additional complexity regarding PRLR function. Therefore, studies assessing the role or association of PRL with tumorigenic potential are more specific to PRL biology than studies investigating the PRLR, which can bind additional ligands. This, however, does not reduce their importance.

When assessing PRL or PRLR function with respect to a biomarker for metastasis or other, it is apparent that there is a complex picture unfolding and often one observes only a glimpse of the intricacy involved. The potential for the prolactin inducible protein (PIP) to be a marker for breast cancer metastasis has been explored (Clark et al. 1999, Mitas et al. 2001). The biology and involvement of PIP is also complex, involves the induction predominantly by other hormones and has been the subject of a recent review (Ihedioha et al. 2016).

\section{PRLR structure and PRLR isoforms}

Greater insight into the structure of the PRLR was recently determined, with the PRLR serving as the archetype of the structure of cytokine class-1 receptors (Haxholm et al. 2015, Bugge et al. 2016) (Fig. 2). Class-1 cytokine receptors, share a common structure, consisting of an extracellular domain, transmembrane domain and an intracellular domain. The receptor chains are already dimerized in the absence of ligand (Gadd \& Clevenger 2006, Tallet et al. 2011). The extracellular domain is divided into two fibronectin 3 domains, D1 and D2, of which the latter contains a WS motif (Fig. 2) that acts as a molecular switch for the PRLR during ligand-bound activation (Dagil et al. 2012). The receptor chain does not possess kinase activity, and it is dependent upon associated kinases for its ability to transduce phosphorylation-based signal cascades. The intracellular domain of the PRLR is disordered and does not appear to be involved in receptor dimerization (Haxholm et al. 2015). The intracellular domain includes Box-1 and Box-2 domains (Fig. 2), the first of which is known to interact with JAK2 and Rous sarcoma oncogene cellular homolog (SRC) family kinases such as FYN (Haxholm et al. 2015).

Interestingly, there are three lipid-interacting domains in the intracellular portion of the molecule (Fig. 2), one of which overlaps with the Box-1 domain, although the interactions are not necessarily mutually exclusive (Haxholm et al. 2015). These lipid-interacting domains (LIDs) may function to focus on signal transduction or have another role in creating specificity or signal transduction pathway choice, and the elucidation of their function will certainly shed light on the cellular context of PRLR function. The lipid content of the membrane may even influence signaling pathway choice downstream of the PRLR. It is not yet known if association of the receptor with the membrane is constitutive or regulated or if

Published by Bioscientifica Ltd 


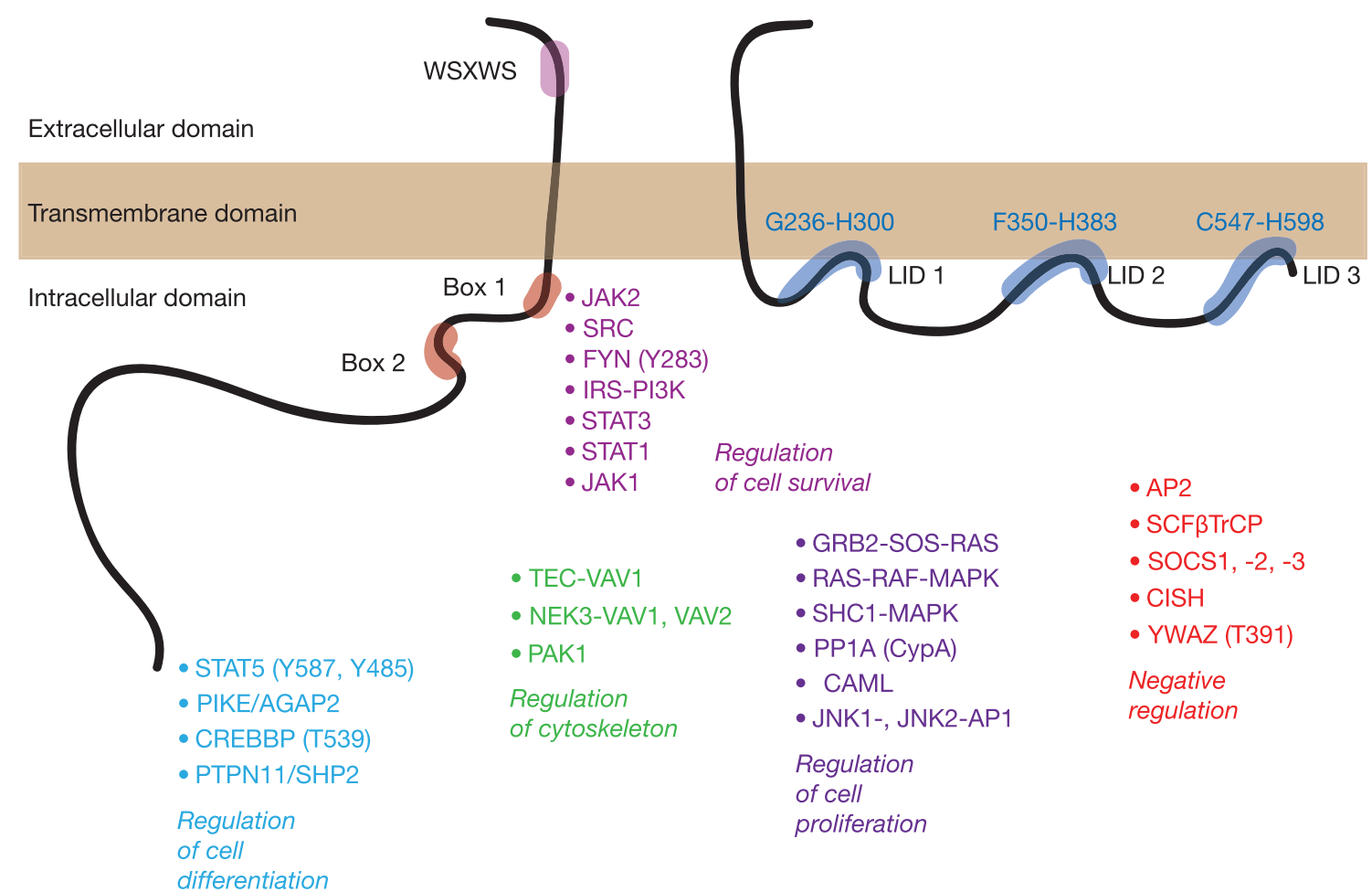

Figure 2

The PRLR consists of three main domains, the extracellular domain, which contains a WS motif that acts as a molecular switch for activation, a transmembrane domain and a disordered intracellular domain. Shown are two different views and two possible orientations of identical receptor chains, showing Box-1, which interacts with JAK2 and SRC family kinases, Box-2 and three lipid-interacting domains (LID) (shown with the amino acids that the LIDs span). The interactions of the LIDs with the plasma membrane are not specific for the state of activation. A number of different proteins listed with some signaling pathway members help perform and regulate activities related to regulation of cell differentiation, the cytoskeleton, cell proliferation, cell survival or the overall function or activity of PRLR signaling (negative regulation). If known, the PRLR amino acid with which they interact is identified.

sub-domains of JAK2 may be involved in mediating the interaction with the receptor (Haxholm et al. 2015).

Multiple human PRLR isoforms add additional complexity to the biology, with up to 8 mRNA variants encoding transmembrane receptors, and 3 possible soluble isoforms (Tsai-Morris \& Dufau 2012) created by alternative splicing or proteolytic cleavage. For the most part, the isoforms differ in length of their intracellular domain, creating differential signal transduction capacity along with only some unique intracellular domains. The major human mRNA variants are capable of encoding a transmembrane isoforms including the long form, short form (SF)1a, SF1b (Trott et al. 2003) and SF1c (Pujianto et al. 2010). The intermediate form of the receptor has some capacity for unique signaling within the intracellular domain (Kline et al. 1999), and the deltaS1 PRLR has reduced signaling capacity due to a shorter extracellular domain (Kline et al. 2002). The soluble forms include delta7/11 (and delta4/11 or delta7/11) (Trott et al. 2003). PRL transcript variants and PRLR isoforms have been covered in a recent review (Bernard et al. 2015).

Given the potential interactive capacity of the different PRLR isoforms that influences signal transduction, one can hypothesize that the ratio in cellular expression of these variants could lead to altered signaling. A soluble form of the receptor is reported to potentially inhibit PRL signaling by binding to PRL (Trott et al. 2003). Additionally, some short forms, in particular SF1b, act as a dominant negative to the long form of the PRLR (Saunier et al. 2003, Tan et al. 2005, Tan \& Walker 2010) and negatively influence STAT5 signaling (Qazi et al. 2006). A low ratio of short-tolong form of the PRLR was also associated with cancerous breast tissue rather than normal matching breast tissue, indicating that the reduction in dominant negative regulation may result in unrestrained PRLR signaling in cancerous breast tissue (Meng et al. 2004).

The presence of these different PRLR isoforms creates an additional layer of complexity with respect to signaling capacity, differential signaling and interactive

Published by Bioscientifica Ltd 
responses leading to altered signaling. In general, it is difficult to ascribe the different published observations to any specific isoform or ratio of isoforms in most reports, unless there were specific mRNA variant analyses, and this is not generally performed with large tissue microarrays. Unfortunately, antibodies specific to individual isoforms are lacking.

\section{PRLR signal transduction}

Few of the potential tyrosine amino acid docking sites in the PRLR have been identified as a specific docking site for a specific signaling protein. Of note, the docking sites for STAT5 (Pezet et al. 1997b, Mayr et al. 1998, Rui and Nevalainen 2003), FYN (Haxholm et al. 2015), CREBbinding protein (CREBBP) (Ma et al. 2010) and 14-3-3 protein zeta/delta (YWAZ) (Olayioye et al. 2003) on the human PRLR, or equivalent site, have been identified (Fig. 2). The distal STAT5 docking site is absent in the majority of the isoforms except for the long form of the PRLR receptor. Therefore, multiple signaling pathways exist downstream and differ, in part, based on the PRLR isoform expressed in the cell. Signaling pathways include those triggered by receptor-bound kinases (Fig. 2) such as JAK2 (DaSilva et al. 1994), SRC, FYN, NIMA (never in mitosis gene a)-related kinase 3 (NEK3) (with VAV1, - 2 and -3) (Miller et al. 2005, Miller et al. 2007) and tyrosine protein kinase (TEC) (with VAV1) (Kline et al. 2001). JAK2 and SRC family kinases FYN and LYN are constitutively associated with the PRLR (Clevenger et al. 1995, Lebrun et al. 1995, Pezet et al. 1997a, Fresno Vara et al. 2001). Activation of the PI3K pathway has been reported via JAK2 and insulin receptor substrate (IRS) recruitment (Yamauchi et al. 1998), as well as via SRC and focal adhesion kinase (FAK) (Acosta et al. 2003). Additional proteins that interact with the receptor to regulate cell survival include JAK1 (Gao et al. 1996, Neilson et al. 2007), STAT1 and STAT3 (DaSilva et al. 1996).

These and other interacting proteins have been recently summarized according to protein-protein interactions in NetSlim (Radhakrishnan et al. 2012) and in BioGRID (Stark et al. 2006). These include proteins that function in cellular differentiation (Fig. 2), such as STAT5 (Wakao et al. 1994), Arf GTPase-activating protein (AGAP-2)/PIKE-A (Chan et al. 2010) and CREBBP, which acetylates the receptor and promotes receptor dimerization and STAT5 activity (Ma et al. 2010). Src Homology Phosphatase-2 (SHP2)/PTPN11 protein tyrosine phosphatase, non-receptor type 11 (Ali \& Ali 2000), promotes STAT5 activation by promoting JAK2 stability
(Ali et al. 2003). Proteins that function in the regulation of the cytoskeleton include TEC-VAV1 and NEK3-VAV-1 and -VAV-2. The p21-activated kinase-1 (PAK1) is an important central modulator that also regulates the cytoskeleton (Fig. 2) (for review see Hammer \& Diakonova 2015).

Regulation of cell proliferation is controlled by pathways involving calcium-modulating cyclophilin ligand (CAML) (Lim et al. 2011), PP1A/cyclophilin peptidylprolyl isomerase-A (cyclophilin A) (Syed et al. 2003), Src Homology-2 Domain-Containing protein (SHC) (Erwin et al. 1995, Das \& Vonderhaar 1996), SHC-Transforming Protein C1 (SHC1), growth factor receptor-bound protein 2 (GRB2)-Son of Sevenless (SOS)-rat sarcoma (RAS) (Erwin et al. 1995, Das \& Vonderhaar 1996), cjun N-terminal kinase-1 (JNK1) and JNK2 (Olazabal et al. 2000, Schwertfeger et al. 2000) (Fig. 2).

PRLR signaling is negatively regulated by a number of proteins and pathways (Fig. 2), such as 14-3-3 protein zeta/delta (YWAZ) (Olayioye et al. 2003), cytokineinducible SH2-containing protein (CISH) (Endo et al. 2003), suppressors of cytokine signaling (SOCS2) (Pezet et al. 1999), SOCS3 (Dif et al. 2001), Skp, Cullin, F-boxcontaining complex (SCF) $\beta \operatorname{TrCP} / \mathrm{F}-\mathrm{box}$ and WD repeat domain-containing 11 FBXW2 (Li et al. 2004), betatransducin repeat containing E3 ubiquitin protein ligase (BTRC) (Li et al. 2006) and general transcription factor IIIA (GTF3A)/AP2 (Varghese et al. 2008), which controls lysosome targeting post ubiquitination. Degradation of the PRLR is regulated by the phosphorylation of serine-349 (Li et al. 2004) by glycogen synthase kinasebeta (Plotnikov et al. 2008), and polyubiquitination by SCF $\beta \operatorname{TrCP}$ (Plotnikov et al. 2008, Varghese et al. 2008). Control over the PRLR protein levels can therefore vary from mRNA levels under different cellular circumstances. Additionally, the natural regulation of PRL induction of PRLR degradation appears to be impaired in breast cancer cells (Li et al. 2006).

The PRLR has crosstalk interactions with several different receptors that can influence signal transduction. The PRLR crosstalks with integrin via the signal regulatory protein alpha (SIRPa) transmembrane glycoprotein and SHP2 (Galbaugh et al. 2010). PRL and estrogen synergistically regulate gene expression (Rasmussen et al. 2010) and constitutive active PRLR variant can inhibit estrogen-induced cellular proliferation (Huang et al. 2015). There are also reports of PRL activating the unliganded estrogen receptor (Arendt \& Schuler 2008a, Gonzalez et al. 2009, O'Leary et al. 2013). PRL and estrogen induce extracellular regulated kinase (ERK)-1, -2

Published by Bioscientifica Ltd. 
phosphorylation and activate the transcription factor, activator protein-1 (AP-1). Crosstalk of the PRLR with the ER has several important implications with respect to breast cancer progression, chemotherapeutic resistance and in particular bone metastases. The PRLR was also shown, via JAK2, to activate HER2 signaling (Yamauchi et al. 2000), as well as estrogen receptor signaling (Arendt $\&$ Schuler 2008b).

It is clear that PRLR signaling must be specific and that cellular context and the microenvironment may very well contribute to pathway choice and function. Cellular context likely plays a critical role in the selection or predominance of particular pathways, which can include cell type, PRLR isoform expression, crosstalk with other pathways and the specific contents of the microenvironment.

\section{Cellular context and the tumor microenvironment}

The stiffness of collagen matrices has been identified as a key factor in PRL-PRLR-pathway choices (Barcus et al. 2013) and crosstalk with estrogen (Barcus et al. 2015). Using in vitro collagen matrices, it was observed that compliant collagen matrix promoted the activation of PRL-STAT5 and cell differentiation, whereas a stiff collagen matrix activated the PRL-SRC-FAK-MAPK signaling and invasive behavior (Barcus et al. 2013, 2016). These observations go a long way to explain why in some cases PRL or PRLR is associated with a good or alternatively poor prognosis. The precise timing of JAK2-STAT5 signaling with respect to early cellular transformation is also likely important, and discussed in the following sections.

A stiff collagen-I matrix modulates the PRL response to involve an increase in the crosstalk of PRL with estrogen (Barcus et al. 2015). High-density collagen-I gels increased the invasive properties of the breast cancer cells in response to estrogen and PRL. The stiff matrix also reduced the sensitivity of the cells to 4-hydroxy-tamoxifen in the presence of both estrogen and PRL. SRC family kinases were implicated in the proliferative responses of the cell lines in stiff matrix. Together, these results show that the microenvironmental conditions, such as matrix stiffness, affect gene regulation and signaling pathway choice that encourages cancer progression, such as proliferation, invasion and drug resistance, rather than encouraging differentiation.

Despite the importance of the tumor microenvironment in PRLR signal pathway choice and crosstalk, the stiffness of the tumor microenvironment is not often investigated when assessing patient samples and PRL signaling. Mammographic density (Li et al. 2005), due to increased fibrillar collagen, would be an interesting clinical feature to additionally analyze when assessing prognosis associated with PRL serum levels or PRLR expression or protein levels. Circulating PRL levels have been linked to mammographic density in postmenopausal women in some studies (Boyd et al. 2002, Greendale et al. 2007, Rice et al. 2015), but not all (Bremnes et al. 2007, Maskarinec et al. 2007), as well as with an inverse correlation to lowdensity breast tissue (McCormack et al. 2009, Rice et al. 2015). It would be intriguing to assess this association with metastasis and survival outcomes.

\section{PRL-JAK2-STAT5 signaling: protective or oncogenic or both?}

There is one major PRLR signal transduction pathway that has received a great deal of attention and has demonstrated to be intricate in its contribution to cancer, with apparent conflicting results presented, until it was understood well. The evidence indicates that the PRL-PRLR-JAK2-STAT5 pathway is important in tumor initiation but not in later progression.

A mouse model of PRL-mediated tumorigenesis showed a role for JAK2 in PRL-induced mammary cancer (Sakamoto et al. 2010) in a timing-dependent manner. Using a mouse model that constitutively expresses rat Prl under the neu-related lipocalin promoter (Rose-Hellekant et al. 2003) crossed to a mouse mammary tumor virus (MMTV)-Cre-recombinase model that conditionally ablates Jak2 in the mammary gland before or after tumor initiation, demonstrated a contributory role for JAK2 in tumor initiation but not post-transformation. This work illustrates a key molecular timing of PRL-JAK2STAT5 in tumor initiation and puts other data exploring this pathway in post-transformation breast cancer cells into context with regard to proliferation. It also illustrated the idea that erythroblastic leukemia viral oncogene (ERBB) family member crosstalk with PRLR signaling may supersede JAK2 functionality.

In support of that early role in transformation, PRLSTAT5 has been reported to interfere with the tumorsuppressive function of breast cancer-1 (BRCA1). PRL and the selective PRLR modulator, S179DPRL, (from both the long and short (SF1b) PRLR isoforms), were able to induce BRCA1 levels, although only PRL was able to interfere with BRCA1-mediated transcriptional

Published by Bioscientifica Ltd. 
activation of the cyclin-dependent kinase inhibitor, p21, via its interaction with STAT5 (Chen \& Walker 2016). Therefore, PRL-STAT5 signaling interferes with BRCA1 tumor-suppressive function of cell cycle inhibition, while allowing proliferation in the presence of PRL.

In vitro studies have indicated that the long form of the PRLR and JAK2 signaling contributed toward an epithelial phenotype, rather than a mesenchymal phenotype (Nouhi et al. 2006). This was shown in T47D cells, which are a luminal subtype (Neve et al. 2006), possibly the more aggressive luminal B (Prat et al. 2013). Overexpression of the PRLR resulted in a reversal of the mesenchymal phenotype in the MDA-MB-231 cells, shown to be similar to the basal-B subtype (Neve et al. 2006). These in vitro results obtained from $2 \mathrm{D}$ cell culture are in agreement with the work by Barcus and coworkers, who demonstrated that breast cancer cells in compliant (vs stiff) collagen matrices activated JAK2-Stat5 signaling rather than MAPK signaling. The microenvironment would explain the in vivo results recently reported, which show that the PRLR long form is important in metastasis (Yonezawa et al. 2015).

In established T47D xenograft tumors in nude mice, PRL-STAT5 activation resulted in increased amounts of E-cadherin (Sultan et al. 2005). These results are consistent with a protective role for STAT5 in cancerous progression, although the effects on early tumor formation or metastasis were not examined. PRL-STAT5 activation was also associated with reduced invasive characteristics in vitro in T47D cells (Sultan et al. 2005).

STAT5 activation, which is also downstream of other cytokine receptors, appears to be associated with a better prognosis in some human studies, where STAT5 activation decreases with cancerous progression and lymph node positivity, and a favorable marker in lymph node-negative disease (Nevalainen et al. 2004, Peck et al. 2011). This could be consistent with the idea that the JAK2-STAT5 pathway favors early cellular transformation, a stage that is generally not captured in tissue microarrays and is later associated with a more differentiated cancer cell phenotype.

\section{The PRLR as a therapeutic target}

Small clinical trials combining antiprolactinemia drugs (bromocriptine or cabergoline), in combination with other chemotherapies (taxotere or triptorelin and tamoxifen) were promising for the treatment of metastatic breast cancer (Lissoni et al. 2002, Lissoni et al . 2003, Frontini et al. 2004). PRLR antagonists are also in development for PRL-related disorders and have been reviewed (Goffin et al. 2005).

A recent informative phase 1 clinical trial for the PRLR antagonist, LFA102, a humanized monoclonal antibody, showed good toleration and apparent efficacy of target, as measured by a surrogate marker, but did not show any anti-primary-tumor activity as a monotherapy in the study of 73 patients with metastatic breast cancer or castrate-resistant prostate cancer (Agarwal et al. 2016). This could be for several reasons within the clinical trial, including a lack of prior selection of the 73 patients for their PRLR expression and protein levels, lengthy dosing intervals with respect to half-life, resulting in reduced drug exposure. A maximum-tolerated dose was not determined due to a lack of dose-limiting toxicities. It was not reported if the tumors were assessed for any compensatory pathways or other compensatory molecular mechanism. There was a large (6-fold) increase in serum prolactin upon PRLR inhibition, apparently similar to what has been reported in mouse models (above). This increase in serum prolactin was used as a surrogate marker for PRLR inhibition, although it was not possible to know if the inhibition was complete with the dose provided. It is possible that better results would be seen if PRLR isoform identification and tumor molecular subtype were taken into consideration (O'Sullivan \& Bates 2016). The utility of LFA102 for hyperprolactinemia, or in combination therapy, in conjunction with HER2 or ER treatments, is still promising for breast cancer.

\section{Impact}

So how does one interpret the potentially conflicting reports of PRLR as a potential biomarker for metastases? Is PRL signaling in breast cancer protective or detrimental? One must take into account the myriad of factors that influence PRL signaling, particularly in vivo. We are just starting to understand the impact of these factors and the role that the PRL-PRLR pathways have on the spectrum of cellular processes that range from a protective nature to accelerating the vicious cycle of bone metastasis.

Evidence shows that high PRL levels are associated with invasive and lymph node-positive disease, but not disease recurrence, in postmenopausal women. Other reports also show that high PRLR expression is associated with better relapse-free survival and better distant metastasisfree survival. This raises the question of whether the PRLR has a role in metastasis that occurs early in the disease, as opposed to one that lies dormant for a period. Certainly, once metastasis to the bone occurs, the likelihood of a

Published by Bioscientifica Ltd 
lytic bone lesion is increased, due to the PRLR in breast cancer cells in the secondary bone site.

Unraveling these factors and pathways in the near future will help define both the protective aspects and the therapeutic targets. It is critical that the network of signaling be well defined to better deliver treatment for PRL-responsive cancers. In some ways, it is not really a question of if PRL could be a biomarker for metastatic risk, but when and how.

\section{Declaration of interest}

The author declares that there is no conflict of interest that could be perceived as prejudicing the impartiality of this review.

\section{Funding}

This review did not receive any specific grant from any funding agency in the public, commercial or not-for-profit sector.

\section{References}

Acosta JJ, Munoz RM, Gonzalez L, Subtil-Rodriguez A, DominguezCaceres MA, Garcia-Martinez JM, Calcabrini A, Lazaro-Trueba I \& Martin-Perez J 2003 Src mediates prolactin-dependent proliferation of T47D and MCF7 cells via the activation of focal adhesion kinase/ Erk1/2 and phosphatidylinositol 3-kinase pathways. Molecular Endocrinology 17 2268-2282. (doi:10.1210/me.2002-0422)

Agarwal N, Machiels JP, Suarez C, Lewis N, Higgins M, Wisinski K, Awada A, Maur M, Stein M, Hwang A, et al. 2016 Phase I study of the prolactin receptor antagonist LFA102 in metastatic breast and castration-resistant prostate cancer. Oncologist 21 535-536. (doi:10.1634/theoncologist.2015-0502)

Ali S \& Ali S 2000 Recruitment of the protein-tyrosine phosphatase SHP-2 to the C-terminal tyrosine of the prolactin receptor and to the adaptor protein Gab2. Journal of Biological Chemistry 275 39073-39080. (doi:10.1074/jbc.M007478200)

Ali S, Nouhi Z, Chughtai N \& Ali S 2003 SHP-2 regulates SOCS-1-mediated Janus kinase-2 ubiquitination/degradation downstream of the prolactin receptor. Journal of Biological Chemistry 278 52021-52031. (doi:10.1074/jbc.M306758200)

Arendt LM \& Schuler LA 2008a Prolactin drives estrogen receptor-alphadependent ductal expansion and synergizes with transforming growth factor-alpha to induce mammary tumors in males. American Journal of Pathology 172 194-202. (doi:10.2353/ajpath.2008.070597)

Arendt LM \& Schuler LA $2008 b$ Transgenic models to study actions of prolactin in mammary neoplasia. Journal of Mammary Gland Biology and Neoplasia 13 29-40. (doi:10.1007/s10911-008-9073-9)

Barcus CE, Holt EC, Keely PJ, Eliceiri KW \& Schuler LA 2015 Dense collagen-I matrices enhance pro-tumorigenic estrogen-prolactin crosstalk in MCF-7 and T47D breast cancer cells. PLOS ONE 10 e0116891. (doi:10.1371/journal.pone.0116891)

Barcus CE, Keely PJ, Eliceiri KW \& Schuler LA 2013 Stiff collagen matrices increase tumorigenic prolactin signaling in breast cancer cells. Journal of Biological Chemistry 288 12722-12732. (doi:10.1074/ jbc.M112.447631)

Barcus CE, Keely PJ, Eliceiri KW \& Schuler LA 2016 Prolactin signaling through focal adhesion complexes is amplified by stiff extracellular matrices in breast cancer cells. Oncotarget 7 48093-48106. (doi:10.1074/jbc.M112.447631)
Ben-Jonathan N, Liby K, McFarland M \& Zinger M 2002 Prolactin as an autocrine/paracrine growth factor in human cancer. Trends in Endocrinology and Metabolism 13 245-250. (doi:10.1016/S10432760(02)00603-3)

Bernard V, Young J, Chanson P \& Binart N 2015 New insights in prolactin: pathological implications. Nature Reviews Endocrinology 11 265-275. (doi:10.1038/nrendo.2015.36)

Boyd NF, Stone J, Martin LJ, Jong R, Fishell E, Yaffe M, Hammond G \& Minkin S 2002 The association of breast mitogens with mammographic densities. British Journal of Cancer $\mathbf{8 7} 876-882$. (doi:10.1038/sj.bjc.6600537)

Bremnes Y, Ursin G, Bjurstam N, Rinaldi S, Kaaks R \& Gram IT 2007 Endogenous sex hormones, prolactin and mammographic density in postmenopausal Norwegian women. International Journal of Cancer 121 2506-2511. (doi:10.1002/ijc.22971)

Brockton NT, Gill SJ, Laborge SL, Paterson AH, Cook LS, Vogel HJ, Shemanko CS, Hanley DA, Magliocco AM \& Friedenreich CM 2015 The breast cancer to bone (B2B) metastases research program: a multi-disciplinary investigation of bone metastases from breast cancer. BMC Cancer 15 512. (doi:10.1186/s12885015-1528-y)

Brooks CL 2012 Molecular mechanisms of prolactin and its receptor. Endocrine Reviews 33 504-525. (doi:10.1210/er.2011-1040)

Bugge K, Papaleo E, Haxholm GW, Hopper JT, Robinson CV, Olsen JG, Lindorff-Larsen K \& Kragelund BB 2016 A combined computational and structural model of the full-length human prolactin receptor. Nature Communications 7 11578. (doi:10.1038/ncomms11578)

Chan CB, Liu X, Ensslin MA, Dillehay DL, Ormandy CJ, Sohn P, Serra R \& Ye K 2010 PIKE-A is required for prolactin-mediated STAT5a activation in mammary gland development. EMBO Journal 29 956-968. (doi:10.1038/emboj.2009.406)

Chen JK, Taipale J, Cooper MK \& Beachy PA 2002 Inhibition of Hedgehog signaling by direct binding of cyclopamine to Smoothened. Genes and Development 16 2743-2748. (doi:10.1101/ gad.1025302)

Chen KH \& Walker AM 2016 Prolactin inhibits a major tumorsuppressive function of wild type BRCA1. Cancer Letters $\mathbf{3 7 5}$ 293-302. (doi:10.1016/j.canlet.2016.03.007)

Clapp C, Thebault S \& Martinez de la Escalera G 2008 Role of prolactin and vasoinhibins in the regulation of vascular function in mammary gland. Journal of Mammary Gland Biology and Neoplasia 13 55-67. (doi:10.1007/s10911-008-9067-7)

Clark JW, Snell L, Shiu RP, Orr FW, Maitre N, Vary CP, Cole DJ \& Watson PH 1999 The potential role for prolactin-inducible protein (PIP) as a marker of human breast cancer micrometastasis. British Journal of Cancer 81 1002-1008. (doi:10.1038/sj.bjc.6690799)

Clement-Lacroix P, Ormandy C, Lepescheux L, Ammann P, Damotte D, Goffin V, Bouchard B, Amling M, Gaillard-Kelly M, Binart N, et al. 1999 Osteoblasts are a new target for prolactin: analysis of bone formation in prolactin receptor knockout mice. Endocrinology 140 96-105. (doi:10.1210/en.140.1.96)

Clevenger CV, Chang WP, Ngo W, Pasha TL, Montone KT \& Tomaszewski JE 1995 Expression of prolactin and prolactin receptor in human breast carcinoma. Evidence for an autocrine/paracrine loop. American Journal of Pathology 146 695-705.

Coskun U, Gunel N, Toruner FB, Sancak B, Onuk E, Bayram O, Cengiz O, Yilmaz E, Elbeg S \& Ozkan S 2003 Serum leptin, prolactin and vascular endothelial growth factor (VEGF) levels in patients with breast cancer. Neoplasma 50 41-46.

Coss D, Yang L, Kuo CB, Xu X, Luben RA \& Walker AM 2000 Effects of prolactin on osteoblast alkaline phosphatase and bone formation in the developing rat. American Journal of Physiology: Endocrinology and Metabolism 279 E1216-E1225.

Dagil R, Knudsen MJ, Olsen JG, O'Shea C, Franzmann M, Goffin V, Teilum K, Breinholt J \& Kragelund BB 2012 The WSXWS motif in cytokine receptors is a molecular switch involved in receptor 
activation: insight from structures of the prolactin receptor. Structure 20 270-282. (doi:10.1016/j.str.2011.12.010)

Das R \& Vonderhaar BK 1996 Involvement of SHC, GRB2, SOS and RAS in prolactin signal transduction in mammary epithelial cells. Oncogene 13 1139-1145.

Das S, Samant RS \& Shevde LA 2011 Hedgehog signaling induced by breast cancer cells promotes osteoclastogenesis and osteolysis. Journal of Biological Chemistry 286 9612-9622. (doi:10.1074/jbc. M110.174920)

DaSilva L, Howard OM, Rui H, Kirken RA \& Farrar WL 1994 Growth signaling and JAK2 association mediated by membrane-proximal cytoplasmic regions of prolactin receptors. Journal of Biological Chemistry 269 18267-18270.

DaSilva L, Rui H, Erwin RA, Zack Howard OM, Kirken RA, Malabarba MG, Hackett RH, Larner AC \& Farrar WL 1996 Prolactin recruits STAT1, STAT3 and STAT5 independent of conserved receptor tyrosines TYR402, TYR479, TYR515 and TYR580. Molecular and Cellular Endocrinology 117 131-140. (doi:10.1016/03037207(95)03738-1)

Dif F, Saunier E, Demeneix B, Kelly PA \& Edery M 2001 Cytokineinducible SH2-containing protein suppresses PRL signaling by binding the PRL receptor. Endocrinology 142 5286-5293. (doi:10.1210/endo.142.12.8549)

Endo T, Sasaki A, Minoguchi M, Joo A \& Yoshimura A 2003 CIS1 interacts with the Y532 of the prolactin receptor and suppresses prolactin-dependent STAT5 activation. Journal of Biochemistry 133 109-113. (doi:10.1093/jb/mvg004)

Erwin RA, Kirken RA, Malabarba MG, Farrar WL \& Rui H 1995 Prolactin activates Ras via signaling proteins SHC, growth factor receptor bound 2, and son of sevenless. Endocrinology 136 3512-3518. (doi:10.1210/en.136.8.3512)

Fresno Vara JA, Caceres MA, Silva A \& Martin-Perez J 2001 Src family kinases are required for prolactin induction of cell proliferation. Molecular Biology of the Cell 12 2171-2183. (doi:10.1091/ mbc.12.7.2171)

Frontini L, Lissoni P, Vaghi M, Perego MS, Pescia S, Ardizzoia A \& Gardani G 2004 Enhancement of the efficacy of weekly low-dose taxotere by the long acting anti-prolactinemic drug cabergoline in pretreated metastatic breast cancer. Anticancer Research $\mathbf{2 4}$ 4223-4226.

Gadd SL \& Clevenger CV 2006 Ligand-independent dimerization of the human prolactin receptor isoforms: functional implications. Molecular Endocrinology 20 2734-2746. (doi:10.1210/me.2006-0114)

Galbaugh T, Feeney YB \& Clevenger CV 2010 Prolactin receptorintegrin cross-talk mediated by SIRPalpha in breast cancer cells. Molecular Cancer Research 8 1413-1424. (doi:10.1158/1541-7786. MCR-10-0130)

Gao J, Hughes JP, Auperin B, Buteau H, Edery M, Zhuang H, Wojchowski DM \& Horseman ND 1996 Interactions among Janus kinases and the prolactin (PRL) receptor in the regulation of a PRL response element. Molecular Endocrinology 10 847-856. (doi:10.1210/ mend10.7.8813725)

Goffin V, Bernichtein S, Touraine P \& Kelly PA 2005 Development and potential clinical uses of human prolactin receptor antagonists. Endocrine Reviews 26 400-422. (doi:10.1210/er.2004-0016)

Gonzalez L, Zambrano A, Lazaro-Trueba I, Lopez E, Gonzalez JJ, Martin-Perez J \& Aranda A 2009 Activation of the unliganded estrogen receptor by prolactin in breast cancer cells. Oncogene $\mathbf{2 8}$ 1298-1308. (doi:10.1038/onc.2008.473)

Greendale GA, Huang MH, Ursin G, Ingles S, Stanczyk F, Crandall C, Laughlin GA, Barrett-Connor E \& Karlamangla A 2007 Serum prolactin levels are positively associated with mammographic density in postmenopausal women. Breast Cancer Research and Treatment 105 337-346. (doi:10.1007/s10549-006-9454-y)

Hachim IY, Hachim MY, Lopez VM, Lebrun JJ \& Ali S 2016a Prolactin receptor expression is an independent favorable prognostic marker in human breast cancer. Applied Immunohistochemistry and Molecular Morphology 24 238-245. (doi:10.1097/PAI.0000000000000178)

Hachim IY, Shams A, Lebrun JJ \& Ali S 2016b A Favorable role of prolactin in human breast cancer reveals novel pathway based gene signatures indicative of tumor differentiation and favorable patient outcome: prolactin-induced mammary differentiation program in breast cancer prognosis. Human Pathology 53 142-152. (doi:10.1016/j.humpath.2016.02.010)

Hammer A \& Diakonova M 2015 Tyrosyl phosphorylated serine-threonine kinase PAK1 is a novel regulator of prolactindependent breast cancer cell motility and invasion. Advances in Experimental Medicine and Biology 846 97-137. (doi:10.1007/978-3319-12114-7_5)

Haxholm GW, Nikolajsen LF, Olsen JG, Fredsted J, Larsen FH, Goffin V, Pedersen SF, Brooks AJ, Waters MJ \& Kragelund BB 2015 Intrinsically disordered cytoplasmic domains of two cytokine receptors mediate conserved interactions with membranes. Biochemical Journal 468 495-506. (doi:10.1042/BJ20141243)

Hess KR, Pusztai L, Buzdar AU \& Hortobagyi GN 2003 Estrogen receptors and distinct patterns of breast cancer relapse. Breast Cancer Research and Treatment 78 105-118. (doi:10.1023/A:1022166517963)

Howell SJ, Anderson E, Hunter T, Farnie G \& Clarke RB 2008 Prolactin receptor antagonism reduces the clonogenic capacity of breast cancer cells and potentiates doxorubicin and paclitaxel cytotoxicity. Breast Cancer Research 10 R68. (doi:10.1186/bcr2129)

Huang KT, Tan D, Chen KH \& Walker AM 2015 Blockade of estrogen-stimulated proliferation by a constitutively-active prolactin receptor having lower expression in invasive ductal carcinoma. Cancer Letters 358 152-160. (doi:10.1016/j.canlet.2014.12.031)

Ihedioha OC, Shiu RP, Uzonna JE \& Myal Y 2016 Prolactin-inducible protein: from breast cancer biomarker to immune modulator-novel insights from knockout mice. DNA and Cell Biology 35 537-541. (doi:10.1089/dna.2016.3472)

Kao J, Salari K, Bocanegra M, Choi YL, Girard L, Gandhi J, Kwei KA, Hernandez-Boussard T, Wang P, Gazdar AF, et al. 2009 Molecular profiling of breast cancer cell lines defines relevant tumor models and provides a resource for cancer gene discovery. PLOS ONE 4 e6146. (doi:10.1371/journal.pone.0006146)

Kline JB, Moore DJ \& Clevenger CV 2001 Activation and association of the Tec tyrosine kinase with the human prolactin receptor: mapping of a Tec/Vav1-receptor binding site. Molecular Endocrinology 15 832-841. (doi:10.1210/mend.15.5.0631)

Kline JB, Roehrs H \& Clevenger CV 1999 Functional characterization of the intermediate isoform of the human prolactin receptor. Journal of Biological Chemistry 274 35461-35468. (doi:10.1074/ jbc.274.50.35461)

Kline JB, Rycyzyn MA \& Clevenger CV 2002 Characterization of a novel and functional human prolactin receptor isoform (deltaS1PRLr) containing only one extracellular fibronectin-like domain. Molecular Endocrinology 16 2310-2322. (doi:10.1210/me.2001-0033)

LaPensee EW, Schwemberger SJ, LaPensee CR, Bahassi el M, Afton SE \& Ben-Jonathan N 2009 Prolactin confers resistance against cisplatin in breast cancer cells by activating glutathione-S-transferase. Carcinogenesis 30 1298-1304. (doi:10.1093/carcin/bgp120)

Lebrun JJ, Ali S, Ullrich A \& Kelly PA 1995 Proline-rich sequencemediated Jak2 association to the prolactin receptor is required but not sufficient for signal transduction. Journal of Biological Chemistry 270 10664-10670. (doi:10.1074/jbc.270.18.10664)

Lee SJ, Park S, Ahn HK, Yi JH, Cho EY, Sun JM, Lee JE, Nam SJ, Yang JH, Park YH, et al. 2011 Implications of bone-only metastases in breast cancer: favorable preference with excellent outcomes of hormone receptor positive breast cancer. Cancer Research and Treatment $\mathbf{4 3}$ 89-95. (doi:10.4143/crt.2011.43.2.89)

Li T, Sun L, Miller N, Nicklee T, Woo J, Hulse-Smith L, Tsao MS, Khokha R, Martin L \& Boyd N 2005 The association of measured breast tissue characteristics with mammographic density and other http://jme.endocrinology-journals.org

DOI: 10.1530/JME-16-0150
๑) 2016 Society for Endocrinology Printed in Great Britain 
risk factors for breast cancer. Cancer Epidemiology Biomarkers and Prevention 14 343-349. (doi:10.1158/1055-9965.EPI-04-0490)

Li Y, Clevenger CV, Minkovsky N, Kumar KG, Raghunath PN, Tomaszewski JE, Spiegelman VS \& Fuchs SY 2006 Stabilization of prolactin receptor in breast cancer cells. Oncogene 25 1896-1902. (doi:10.1038/sj.onc.1209214)

Li Y, Kumar KG, Tang W, Spiegelman VS \& Fuchs SY 2004 Negative regulation of prolactin receptor stability and signaling mediated by SCF(beta-TrCP) E3 ubiquitin ligase. Molecular and Cellular Biology 24 4038-4048. (doi:10.1128/МСB.24.9.4038-4048.2004)

Lim JH, Kim TY, Kim WH \& Park JW 2011 CAML promotes prolactindependent proliferation of breast cancer cells by facilitating prolactin receptor signaling pathways. Breast Cancer Research and Treatment 130 19-27. (doi:10.1007/s10549-010-1274-4)

Lissoni P, Bucovec R, Malugani F, Ardizzoia A, Villa S, Gardani GS, Vaghi M \& Tancini G 2002 A clinical study of taxotere vs taxotere plus the antiprolactinemic agent bromocriptine in metastatic breast cancer pretreated with anthracyclines. Anticancer Research 22 1131-1134.

Lissoni P, Vaghi M, Villa S, Bodraska A, Cerizza L, Tancini G \& Gardani GS 2003 Antiprolactinemic approach in the treatment of metastatic breast cancer: a phase II study of polyneuroendocrine therapy with LHRH-analogue, tamoxifen and the long-acting antiprolactinemic drug cabergoline. Anticancer Research 23 733-736.

Ma L, Gao JS, Guan Y, Shi X, Zhang H, Ayrapetov MK, Zhang Z, Xu L, Hyun YM, Kim M, et al. 2010 Acetylation modulates prolactin receptor dimerization. PNAS 107 19314-19319. (doi:10.1073/ pnas.1010253107)

Maskarinec G, Takata Y, Chen Z, Gram IT, Nagata C, Pagano I, Hayashi K, Arendell L, Skeie G, Rinaldi S, et al. 2007 IGF-I and mammographic density in four geographic locations: a pooled analysis. International Journal of Cancer 121 1786-1792. (doi:10.1002/ ijc.22834)

Mayr S, Welte T, Windegger M, Lechner J, May P, Heinrich PC, Horn F \& Doppler W 1998 Selective coupling of STAT factors to the mouse prolactin receptor. European Journal of Biochemistry 258 784-793. (doi:10.1046/j.1432-1327.1998.2580784.x)

McCormack VA, Dowsett M, Folkerd E, Johnson N, Palles C, Coupland B, Holly JM, Vinnicombe SJ, Perry NM \& dos Santos Silva I 2009 Sex steroids, growth factors and mammographic density: a cross-sectional study of UK postmenopausal Caucasian and Afro-Caribbean women. Breast Cancer Research 11 R38. (doi:10.1186/ bcr2325)

Meng J, Tsai-Morris CH \& Dufau ML 2004 Human prolactin receptor variants in breast cancer: low ratio of short forms to the long-form human prolactin receptor associated with mammary carcinoma. Cancer Research 64 5677-5682. (doi:10.1158/0008-5472.CAN-041019)

Miller SL, Antico G, Raghunath PN, Tomaszewski JE \& Clevenger CV 2007 Nek3 kinase regulates prolactin-mediated cytoskeletal reorganization and motility of breast cancer cells. Oncogene $\mathbf{2 6}$ 4668-4678. (doi:10.1038/sj.onc.1210264)

Miller SL, DeMaria JE, Freier DO, Riegel AM \& Clevenger CV 2005 Novel association of Vav2 and Nek3 modulates signaling through the human prolactin receptor. Molecular Endocrinology 19 939-949. (doi:10.1210/me.2004-0443)

Mitas M, Mikhitarian K, Walters C, Baron PL, Elliott BM, Brothers TE, Robison JG, Metcalf JS, Palesch YY, Zhang Z, et al. 2001 Quantitative real-time RT-PCR detection of breast cancer micrometastasis using a multigene marker panel. International Journal of Cancer 93 162-171. (doi:10.1002/ijc.1312)

Neilson LM, Zhu J, Xie J, Malabarba MG, Sakamoto K, Wagner KU, Kirken RA \& Rui H 2007 Coactivation of janus tyrosine kinase (Jak)1 positively modulates prolactin-Jak2 signaling in breast cancer: recruitment of ERK and signal transducer and activator of transcription (Stat)3 and enhancement of Akt and Stat5a/b pathways. Molecular Endocrinology 21 2218-2232. (doi:10.1210/ me.2007-0173)

Nevalainen MT, Xie J, Torhorst J, Bubendorf L, Haas P, Kononen J, Sauter G \& Rui H 2004 Signal transducer and activator of transcription-5 activation and breast cancer prognosis. Journal of Clinical Oncology 22 2053-2060. (doi:10.1200/JCO.2004.11.046)

Neve RM, Chin K, Fridlyand J, Yeh J, Baehner FL, Fevr T, Clark L, Bayani N, Coppe JP, Tong F, et al. 2006 A collection of breast cancer cell lines for the study of functionally distinct cancer subtypes. Cancer Cell 10 515-527. (doi:10.1016/j.ccr.2006.10.008)

Nitze LM, Galsgaard ED, Din N, Lund VL, Rasmussen BB, Berchtold MW, Christensen L \& Panina S 2013 Reevaluation of the proposed autocrine proliferative function of prolactin in breast cancer. Breast Cancer Research and Treatment 142 31-44. (doi:10.1007/s10549-0132731-7)

Nouhi Z, Chughtai N, Hartley S, Cocolakis E, Lebrun JJ \& Ali S 2006 Defining the role of prolactin as an invasion suppressor hormone in breast cancer cells. Cancer Research 66 1824-1832. (doi:10.1158/00085472.CAN-05-2292)

O’Leary KA, Jallow F, Rugowski DE, Sullivan R, Sinkevicius KW, Greene GL \& Schuler LA 2013 Prolactin activates ERalpha in the absence of ligand in female mammary development and carcinogenesis in vivo. Endocrinology 154 4483-4492. (doi:10.1210/ en.2013-1533)

O"Sullivan CC \& Bates SE 2016 Targeting prolactin receptor (PRLR) signaling in PRLR-positive breast and prostate cancer. Oncologist 21 523-526. (doi:10.1634/theoncologist.2016-0108)

Olayioye MA, Guthridge MA, Stomski FC, Lopez AF, Visvader JE \& Lindeman GJ 2003 Threonine 391 phosphorylation of the human prolactin receptor mediates a novel interaction with 14-3-3 proteins. Journal of Biological Chemistry 278 32929-32935. (doi:10.1074/jbc. M302910200)

Olazabal I, Munoz J, Ogueta S, Obregon E \& Garcia-Ruiz JP 2000 Prolactin (PRL)-PRL receptor system increases cell proliferation involving JNK (c-Jun amino terminal kinase) and AP-1 activation: inhibition by glucocorticoids. Molecular Endocrinology 14 564-575. (doi:10.1210/mend.14.4.0442)

Peck AR, Witkiewicz AK, Liu C, Stringer GA, Klimowicz AC, Pequignot E, Freydin B, Tran TH, Yang N, Rosenberg AL, et al. 2011 Loss of nuclear localized and tyrosine phosphorylated Stat5 in breast cancer predicts poor clinical outcome and increased risk of antiestrogen therapy failure. Journal of Clinical Oncology 29 2448-2458. (doi:10.1200/JCO.2010.30.3552)

Pezet A, Buteau H, Kelly PA \& Edery M 1997a The last proline of Box 1 is essential for association with JAK2 and functional activation of the prolactin receptor. Molecular and Cellular Endocrinology 129 199-208. (doi:10.1016/S0303-7207(97)00063-4)

Pezet A, Favre H, Kelly PA \& Edery M 1999 Inhibition and restoration of prolactin signal transduction by suppressors of cytokine signaling. Journal of Biological Chemistry 274 24497-24502. (doi:10.1074/ jbc.274.35.24497)

Pezet A, Ferrag F, Kelly PA \& Edery M 1997b Tyrosine docking sites of the rat prolactin receptor required for association and activation of stat5. Journal of Biological Chemistry 272 25043-25050. (doi:10.1074/ jbc.272.40.25043)

Plotnikov A, Li Y, Tran TH, Tang W, Palazzo JP, Rui H \& Fuchs SY 2008 Oncogene-mediated inhibition of glycogen synthase kinase 3 beta impairs degradation of prolactin receptor. Cancer Research $\mathbf{6 8}$ 1354-1361. (doi:10.1158/0008-5472.CAN-07-6094)

Prat A, Karginova O, Parker JS, Fan C, He X, Bixby L, Harrell JC, Roman E, Adamo B, Troester M, et al. 2013 Characterization of cell lines derived from breast cancers and normal mammary tissues for the study of the intrinsic molecular subtypes. Breast Cancer Research and Treatment 142 237-255. (doi:10.1007/s10549-013-2743-3)

Pujianto DA, Curry BJ \& Aitken RJ 2010 Prolactin exerts a prosurvival effect on human spermatozoa via mechanisms that involve the

Published by Bioscientifica Ltd 
stimulation of Akt phosphorylation and suppression of caspase activation and capacitation. Endocrinology 151 1269-1279. (doi:10.1210/en.2009-0964)

Qazi AM, Tsai-Morris CH \& Dufau ML 2006 Ligand-independent homo- and heterodimerization of human prolactin receptor variants: inhibitory action of the short forms by heterodimerization. Molecular Endocrinology 20 1912-1923. (doi:10.1210/me.2005-0291)

Radhakrishnan A, Raju R, Tuladhar N, Subbannayya T, Thomas JK, Goel R, Telikicherla D, Palapetta SM, Rahiman BA, Venkatesh DD, et al. 2012 A pathway map of prolactin signaling. Journal of Cell Communication and Signaling 6 169-173. (doi:10.1007/s12079-012-0168-0)

Rasmussen LM, Frederiksen KS, Din N, Galsgaard E, Christensen L, Berchtold MW \& Panina S 2010 Prolactin and oestrogen synergistically regulate gene expression and proliferation of breast cancer cells. Endocrine-Related Cancer 17 809-822. (doi:10.1677/ERC09-0326)

Rice MS, Tworoger SS, Bertrand KA, Hankinson SE, Rosner BA, Feeney YB, Clevenger CV \& Tamimi RM 2015 Immunoassay and $\mathrm{Nb} 2$ lymphoma bioassay prolactin levels and mammographic density in premenopausal and postmenopausal women the Nurses' Health Studies. Breast Cancer Research and Treatment 149 245-253. (doi:10.1007/s10549-014-3232-z)

Rose-Hellekant TA, Arendt LM, Schroeder MD, Gilchrist K, Sandgren EP \& Schuler LA 2003 Prolactin induces ERalpha-positive and ERalpha-negative mammary cancer in transgenic mice. Oncogene 22 4664-4674. (doi:10.1038/sj.onc.1206619)

Rui H \& Nevalainen MT 2003 Prolactin. In The Cytokine Handbook, 4th edn. Eds A Thomson \& M Lotze. London, UK: Academic Press. (doi:10.1038/sj.onc.1206619)

Sakamoto K, Triplett AA, Schuler LA \& Wagner KU 2010 Janus kinase 2 is required for the initiation but not maintenance of prolactin-induced mammary cancer. Oncogene 29 5359-5369. (doi:10.1038/onc.2010.274)

Saunier E, Dif F, Kelly PA \& Edery M 2003 Targeted expression of the dominant-negative prolactin receptor in the mammary gland of transgenic mice results in impaired lactation. Endocrinology 144 2669-2675. (doi:10.1210/en.2002-221038)

Schwertfeger KL, Hunter S, Heasley LE, Levresse V, Leon RP, DeGregori J \& Anderson SM 2000 Prolactin stimulates activation of c-jun N-terminal kinase (JNK). Molecular Endocrinology 14 1592-1602. (doi:10.1210/mend.14.10.0536)

Stark C, Breitkreutz BJ, Reguly T, Boucher L, Breitkreutz A \& Tyers M 2006 BioGRID: a general repository for interaction datasets. Nucleic Acids Research 34 D535-D539. (doi:10.1093/nar/gkj109)

Sultan AS, Xie J, LeBaron MJ, Ealley EL, Nevalainen MT \& Rui H 2005 Stat5 promotes homotypic adhesion and inhibits invasive characteristics of human breast cancer cells. Oncogene 24 746-760. (doi:10.1038/sj.onc.1208203)

Sutherland A, Forsyth A, Cong Y, Grant L, Juan TH, Lee JK, Klimowicz A, Petrillo SK, Hu J, Chan A, et al. 2016 The role of prolactin in bone metastasis and breast cancer cell-mediated osteoclast differentiation. Journal of the National Cancer Institute 108 djv338. (doi:10.1093/jnci/djv338)

Syed F, Rycyzyn MA, Westgate L \& Clevenger CV 2003 A novel and functional interaction between cyclophilin $\mathrm{A}$ and prolactin receptor. Endocrine 20 83-90. (doi:10.1385/ENDO:20:1-2:83)

Tallet E, Fernandez I, Zhang C, Salsac M, Gregor N, Ayoub MA, Pin JP, Trinquet E \& Goffin V 2011 Investigation of prolactin receptor activation and blockade using time-resolved fluorescence resonance energy transfer. Frontiers in Endocrinology 2 29. (doi:10.3389/ fendo.2011.00029)

Tan D, Johnson DA, Wu W, Zeng L, Chen YH, Chen WY, Vonderhaar BK \& Walker AM 2005 Unmodified prolactin (PRL) and S179D PRL-initiated bioluminescence resonance energy transfer between homo- and hetero-pairs of long and short human PRL receptors in living human cells. Molecular Endocrinology 19 1291-1303. (doi:10.1210/me.2004-0304)

Tan D \& Walker AM 2010 Short form 1b human prolactin receptor down-regulates expression of the long form. Journal of Molecular Endocrinology 44 187-194. (doi:10.1677/JME-09-0101)

Tikk K, Sookthai D, Johnson T, Rinaldi S, Romieu I, Tjonneland A, Olsen A, Overvad K, Clavel-Chapelon F, Baglietto L, et al. 2014 Circulating prolactin and breast cancer risk among pre- and postmenopausal women in the EPIC cohort. Annals of Oncology 25 1422-1428. (doi:10.1093/annonc/mdu150)

Trott JF, Hovey RC, Koduri S \& Vonderhaar BK 2003 Alternative splicing to exon 11 of human prolactin receptor gene results in multiple isoforms including a secreted prolactin-binding protein. Journal of Molecular Endocrinology 30 31-47. (doi:10.1677/ jme.0.0300031)

Tsai-Morris CH \& Dufau ML 2012 PRLR (prolactin receptor). Atlas of Genetics and Cytogenetics in Oncology and Haemtaology 5 1-5.

Tworoger SS, Eliassen AH, Zhang X, Qian J, Sluss PM, Rosner BA \& Hankinson SE 2013 A 20-year prospective study of plasma prolactin as a risk marker of breast cancer development. Cancer Research $\mathbf{7 3}$ 4810-4819. (doi:10.1158/0008-5472.CAN-13-0665)

Varghese B, Barriere H, Carbone CJ, Banerjee A, Swaminathan G, Plotnikov A, Xu P, Peng J, Goffin V, Lukacs GL, et al. 2008 Polyubiquitination of prolactin receptor stimulates its internalization, postinternalization sorting, and degradation via the lysosomal pathway. Molecular and Cellular Biology 28 5275-5287. (doi:10.1128/MCB.00350-08)

Wakao H, Gouilleux F \& Groner B 1994 Mammary gland factor (MGF) is a novel member of the cytokine regulated transcription factor gene family and confers the prolactin response. EMBO Journal $\mathbf{1 3}$ 2182-2191.

Wei B, Wang J, Bourne P, Yang Q, Hicks D, Bu H \& Tang P 2008 Bone metastasis is strongly associated with estrogen receptorpositive/progesterone receptor-negative breast carcinomas. Human Pathology 39 1809-1815. (doi:10.1016/j.humpath.2008.05.010)

Yamauchi T, Kaburagi Y, Ueki K, Tsuji Y, Stark GR, Kerr IM, Tsushima T, Akanuma Y, Komuro I, Tobe K, et al. 1998 Growth hormone and prolactin stimulate tyrosine phosphorylation of insulin receptor substrate-1, -2, and -3 , their association with p85 phosphatidylinositol 3-kinase (PI3-kinase), and concomitantly PI3-kinase activation via JAK2 kinase. Journal of Biological Chemistry 273 15719-15726. (doi:10.1074/jbc.273.25.15719)

Yamauchi T, Yamauchi N, Ueki K, Sugiyama T, Waki H, Miki H, Tobe K, Matsuda S, Tsushima T, Yamamoto T, et al. 2000 Constitutive tyrosine phosphorylation of ErbB-2 via Jak2 by autocrine secretion of prolactin in human breast cancer. Journal of Biological Chemistry 275 33937-33944. (doi:10.1074/jbc.M000743200)

Yonezawa T, Chen KH, Ghosh MK, Rivera L, Dill R, Ma L, Villa PA, Kawaminami M \& Walker AM 2015 Anti-metastatic outcome of isoform-specific prolactin receptor targeting in breast cancer. Cancer Letters 366 84-92. (doi:10.1016/j.canlet.2015.06.010)

Received in final form 14 September 2016

Accepted 22 September 2016

Accepted Preprint published online 22 September 2016 http://jme.endocrinology-journals.org

DOI: 10.1530/JME-16-0150
๑ 2016 Society for Endocrinology Printed in Great Britain
Published by Bioscientifica Ltd 